\title{
Analysis of Energy Yields from Selected Types of Photovoltaic Panels
}

\author{
Sławomir Rabczak ${ }^{*}$, Danuta Proszak-Miąsik¹ \\ 1 Department of Heat Engineering and Air-Conditioning, Rzeszów University of Technology, \\ al. Powstańców Warszawy 12, 35-084 Rzeszów, Poland \\ * Corresponding author's e-mail: rabczak@prz.edu.pl
}

\begin{abstract}
This paper presents the results of the conducted analysis on the on-grid photovoltaic installations designed for a single-family house by applying three different technologies (monocrystalline, polycrystalline and thin-film modules), compared to a simulation of the off-grid polycrystalline technology. As a result of the analysis conducted, the differences between the on-grid and off-grid systems could be determined. The simulation was made on the basis of the PV SOL program which allowed performing calculations concerning monthly and yearly yields during the period of 25 years, taking into account the average degradation of efficiency at $0.8 \%$ monthly. Additinoally, a return rate on investment was determined for different types of the analysed installations, taking into account an increase of electricity prices at $2.5 \%$ annually and a fixed subscriber's fee (assumed as 38 euro monthly). Energy density (amount of energy acquired from $1 \mathrm{~m}^{2}$ of the installation) and the amount of energy necessary to be purchased additionally from the electricity supplier to fully cover the demand for electricity for the analysed building were analysed as well.
\end{abstract}

Keywords: photovoltaics, PV cells, on-grid installation, environmental engineering

\section{INTRODUCTION}

The photovoltaic effect has been known for almost two hundred years. However, it was not been used for power purposes until the end of the first half of the 20th century. The process of the development of such a technology seems to be relatively long but the increase of conventional fuel prices and the increasing care for the natural environment have enforced a growth of popularity of alternative solutions of energy acquiring. At the end of the 20th century and the beginning of the 21 st century, the silicon era contributed to a technological progress. The demand for electricity increased. Households started being equipped with electrically powered devices. The production processes of silicon semi-conductor elements started being applied also in the production of photovoltaic cells [American Physical Society, 2009]. Photovoltaics, just like wind energy, is presently a very dynamically developing technology. It is widely applied not only in a form of large photovoltaic farms (power stations), as independent systems are becoming more and more common. The Sun energy rapidly enters our reality from small garden lamps, through traffic lights, to electrically powered space stations. Similarly as in the case of each new technology, discussions whether such alternative sources of energy will replace the conventional sources in the future have ensued. Such issues concern above all efficiency and cost-effectiveness. It seems that just like wind, the solar energy is for free but the investment costs often obscure the fact that it is also a clean energy.

\section{PHOTOVOLTAIC PANELS}

A solar cell is a basic element of the photovoltaic system which creates a source of constant voltage in participation with the Sun. Grouped and combined, the cells create photovoltaic modules. Such modules, after being connected with one another, form photovoltaic panels (PV generators). The photovoltaic cells may be presently 
divided into 3 groups which are called generations [Góralczyk, Tytko, 2015].

The first generation cells are based on the technology of crystalline silicon. Theoretically, silicon is an element available in unlimited amounts. It is the second most common element in the world and it appears both in a clear form and in chemical compounds. Such cells are made by applying monocrystalline or polycrystalline technologies and they are most common (constitute approx. 89\% of the market) [Adeeb, Farhan, Al-Salaymeh, 2019]. The first generation technologies are so called thick-film technologies. The monocrystalline silicon (mono-Si) cells manufactured by applying this technology, may be distinguished by a characteristic consistent dark-blue colour and bevelled or rounded edges. Optimisation of silicon wafer surfaces is carried out through the Czochralski process (the silicon acquired from this process has a form of a cylinder which is then cut into separate wafers). Such a process is relatively expensive on a large scale but its advantage is that the silicon used for the production of such cells may come from waste products, for example a part of a silicon bar which is too contaminated for the production of transistor systems. The panels manufactured by applying such a technology are sensitive especially to the upper spectrum of visible and infra-red radiation. Unfortunately, such panels are also very susceptible to a temperature rise which results in the decrease of their efficiency. Monocrystallines are obtained most often through crystallisation of melted fluid, as described in the Bridgman technique, the Czocharski process and zone melting [American Physical Society, 2009]. Approx. 80\% of monocrystallines are manufactured through the Czocharski process. In Poland, the production of polycrystalline silicon is presently the cheapest. The panels applying such a technology may be distinguished by characteristic pattern of flakes/scales and a blue colour. They are made by welding and cooling smaller silicon crystals [Góralczyk, Tytko, 2015]. The subsequent production stages of polycrystalline plates are very complex and include, inter alia: grinding (which allows to reveal the crystalline structure), applying electrodes metalised by using screen printing and applying an anti-reflective coating which increases the amount of the light absorbed [Adeeb, . Farhan, Al-Salaymeh, 2019]. They are sensitive to the lower range of visible light, especially to blue light. The tendency towards the production of increasingly larger polycrystalline cells can be observed. This allows to lower the production costs of such modules (the number of cells forming the module is smaller), but then in the process of designing the remaining elements of the installation, it is necessary to take into account higher values of amperage and of cell operation temperature.

The next generation of photovoltaic cells are the thin-film cells. In such a technology, the layer of the active semi-conductor is even a hundred times thinner than it is in first generation cells and has a thickness of approx. a few micrometers. A reduction of semi-conductor wear ensures a favourable relation of price to power [Hoa Thanh Nguyen, Nguyen, Thi Lan, 2019]. An additional advantage of such a technology is that the readymade product is a thin foil which is suitable for light structures. Presently, three types of thin-film cells are used: amorphous silicon cells, cadmium telluride cells and cells from copper indium selenide and copper indium gallium selenide [Klugmann-Radziemska, 2014]. Amorphous cells are a technology based on forming very thin layers of silicon on the surface, for example of glass. Then a ready photovoltaic panel is created, because no particular cells may be isolated. During their production there is no material loss resulting from cutting. Therefore, the production costs are evidently lower than in the case of the first generation cells. Additionally, a temperature rise improves the cell efficiency but it should be remembered that after irradiation, the efficiency stabilises at a lower level (even down to $35 \%$ of the initial value) [Szymański, 2013]. They are usually used to power small devices.

The third generation PV cells are employed in many technologies. They are based on nontoxic, generally available materials and, therefore, their production time is relatively short and production costs are relatively low. However, the difference is that they do not cooperate with classical semi-conductors and their efficiency is very low. The third generation cells are thin, very light and flexible. Additionally, they are totally recyclable. The third generation cells include the cells from organic materials. Organic PV cells consist of: separate layers, solid organic materials and a mixture of organic materials. They are built in a form of a donor-acceptor heterojunction. A strong electric field appears at the junction of two different materials (as a result of the difference in electron affinities and ionisation potentials). Their 
efficiency is approx. $10 \%$ and is almost half of the efficiency of silicon cells, but their production is cheaper. The simplicity of the production process is the main advantage of such a technology, which allows for production on a mass scale. In the process, a layer of semi-conductive polymers (in a form of printing) is placed on a plastic base. The next third generation cell is a dye-sensitised cell. The performance of this type of cells is based on a reversible photochemical process. Light absorption and charge transfer are divided between its various elements. The dye which participates in light absorption does not transfer charges. Such a cell consists of two glass plates. Each of them is covered on one side with a transparent and conductive layer of tin and indigo oxide or tin oxide or tin dioxide. Additionally, the cell front plate is covered with a thin layer of platinum. Between the glass plates, there is a layer of titanium dioxide which is a porous membrane of a great surface. It is saturated with electrolyte (solution of iodine and potassium iodide in ethylene glycol) and conducts the electric current. It is also a carrier of organic dye molecules. Such cells are sensibilised with dyes and, thus, the colour sensitivity of lightsensitive layers is changed. Consequently, the sensibility of reagents to solar radiation is changed. Their efficiency is low and amounts to approx. $2.5 \%$, but -taking into account other organic and non-organic materials - it is the most promising technology [Klugmann-Radziemska, 2014]].

\section{ON-GRID AND OFF-GRID INSTALLATIONS}

Independent photovoltaic systems, i.e. systems which operate to meet the needs for power of the installation in which they operate, can be divided into on-grid and off-grid. The on-grid installation consists of PV panels, structural wiring and DC/AC inverter having a function of synchonisation with the $230 \mathrm{~V}$ grid of the supplier.

The systems connected to the power grid (on-grid) are most popular, but their application is quite limited. It results from the necessity to connect the installation to the power grid. They may be divided into distributed or centralised systems [Adeeb, Farhan, Al-Salaymeh, 2019]. The distributed systems include private single-family house roofs, school roofs and panels integrated with façades. The centralised systems include power stations (wind farms), multi-family buildings (community of owners) and noise barriers.

The off-grid installations are also called isolated installations and they differ in that they use an energy storage which allows them to operate both synchronised with the grid and as completely independent systems. The design of such a complicated variant is different due to the application of a more complex inverter. Energy storages are usually connected to an inverter in parallel through dedicated control electronics, consisting in a charge system and a safety unit. The contemporary energy storages use lithium and polymer packages or lithium and ionic cells which makes them more susceptible to failures when the charging voltage or output current are exceeded. Independent installations consist of a charging regulator, battery, voltage regulator and a PV generator [Adeeb, Farhan, Al-Salaymeh, 2019]. Presently, the price of such energy storages can be twice higher than the price of the remaining part of the installation, so mainly such a solution is mainly applied by the people caring

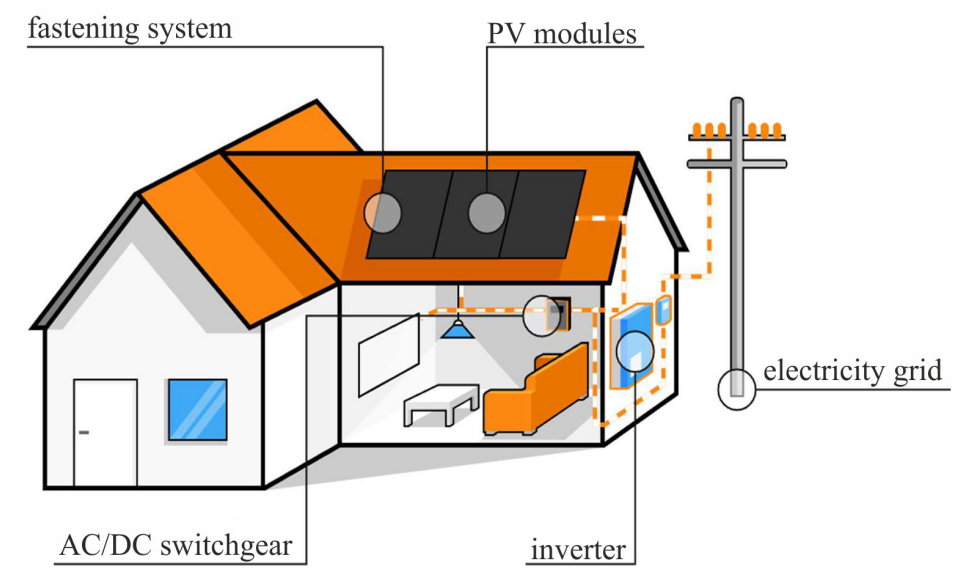

Fig. 1. Scheme of PV installation for a single-family building 
about power independence. However, the off-grid systems have a limited lifetime and a decrease of energy storage capacity should also be taken into account. After several years, a regeneration or repair of the energy storage may be necessary, which may significantly affect the profitability of the whole investment. However, the surveys on the application of graphene for building batteries give hopes that in the future, the off-grid systems will operate longer and, thus, will become costeffective for consumers.

The isolated (off-grid) systems have a wider application than the on-grid systems. Owing to their independence of the power grid, they are used in the places where power grid cables do not reach or where mobility counts. They may be divided into three main groups. The first group includes individual applications such as: internal panels (for example calculators, electronic weights, clocks, watches, electric tools, mobile phones) and external panels (for examples chargers, fountains, torches, garden lights, highlighted house numbers, car ventilation, boats, yachts). The second group are industrial applications such as: telecommunication, road traffic, railroad or maritime signalling, noticeboards, navigation lights, cathodic protection, supervisory control, mountain hotels and restaurants, medical coolers. The third group are the solutions which are used far away from the places of residence (without access to the grid). Such a group includes: street lighting, solar house systems, rural sources of power, battery charging, water purification, irrigation, street lamps and schools [KlugmannRadziemska, 2014].

\section{ANALYSIS OF ENERGY YIELDS FOR SELECTED TYPES OF PV PANELS}

The simulations of energy yields for PV panels were performed for a single-family building with panels installed on the roof. The building is located in the city of Rzeszów, Poland. The simulation included 4 variants and took into account 3 different technologies of photovoltaic cells. The aim of the conducted analysis was to compare energy efficiency and cost-effectiveness of the solutions applied. Monocrytalline, polycrystalline and thin-film cells made in the on-grid system were taken for the analysis and also a simulation for polycrystalline cells operating in the off-grid system was shown. As a result of the simulation performed on the basis of the PV SOL program, the yields from the photovoltaic installation and forecast yields in subsequent years of installation operation were determined (taking into account the average yearly degradation at $0.8 \%$ ). Additionally, the balance between the sold energy and the energy bought from the energy supplier as well as a table showing the time of return on investment (taking into account the average yearly increase of energy prices at $2.5 \%$ annually) were presented. It was assumed that the single-family building is located in Rzeszów on a plot of $568 \mathrm{~m}^{2}$ in area, with a roof area of $188 \mathrm{~m}^{2}$. The angle of inclination of the roof is $37^{\circ}$ and its azimuth is $180^{\circ}$. Figure 2 presents a visualisation of the analysed building made in the PV SOL program.

It should be stressed that owing to the possibility to model the surroundings and the building itself, the path of the shadow moving on each day

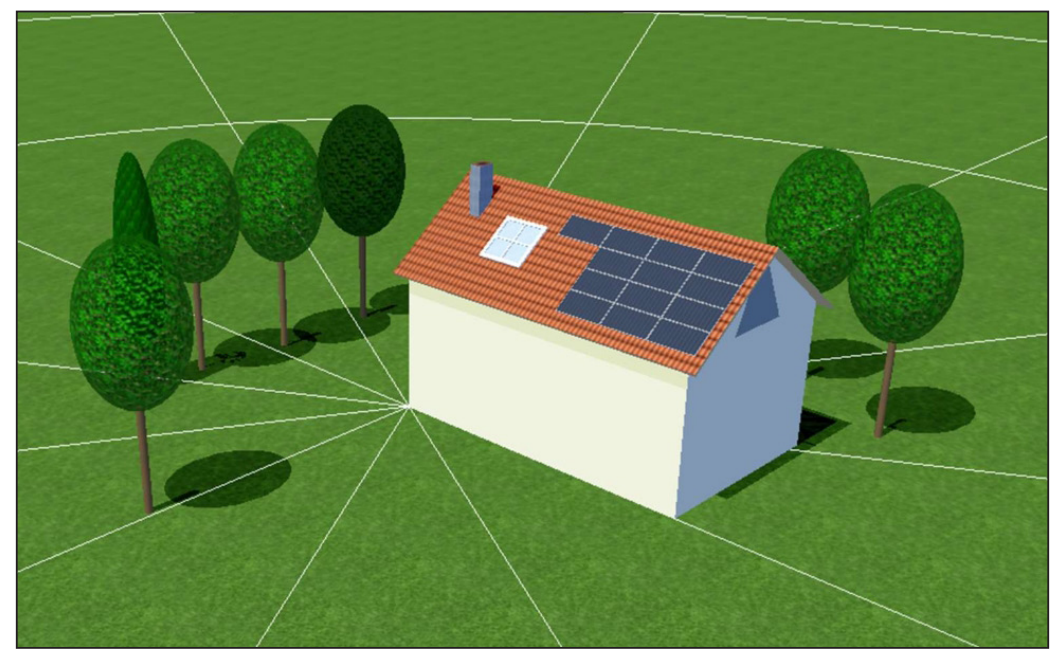

Fig. 2. Visualisation of the analysed building according to PV SOL program 
during a year can be determined and, consequently, the average shading for each particular module for each individual investment can be calculated. The distance between modules is determined on the basis of the longitude and latitude, building/ structure orientation, angle of inclination and shading elements. In the described case, the minimum distance between the modules is $1.3 \mathrm{~m}$ and for such a distance, the degree of shading of the modules is below $1 \%$ annually. For the modules located on the roof, the distance between the modules is $2 \mathrm{~cm}$. It results from the applied system structure.

An installation with an annual consumption of electricity at $3000 \mathrm{kWh}$ was assumed for calculation. According to B. Szymański, approx. $1.25 \mathrm{kWh}$ of PV installation power should be taken per each consumed $1000 \mathrm{kWh}$ of energy annually [6]. In this paper $1.40 \mathrm{~kW}$ of installation power was assumed per each $1000 \mathrm{kWh}$ to compensate for the wear of the installation during the period of 25 years. The program generates a report which shows an annual energy surplus to be used, including $20 \%$ fee for the power plant. If such a value is positive, it is not necessary to buy more energy. A negative value shows the need to buy the energy from the supplier. The amount of additional energy which must be bought annually from the supplier was indicated as a module from the annual negative surplus. It was assumed that the fixed fees are 160 PLN/year and the energy price is $0.13 \mathrm{EUR} / \mathrm{kWh}$. The energy price increase was assumed to be $2.5 \%$ annually. Thus, a yearly cost of additional energy to be bought during the period of 25 years was calculated. The return rate was calculated on the basis of the product catalogue prices and yearly energy cost.

\section{Simulation for On-Grid Monocrystalline Installation}

In the analysed case, 13 monocrystalline modules with the dimensions of $1960 \times 992 \times 40 \mathrm{~mm}$ and a total power of $4.1 \mathrm{~kW}$ were used. Figure 3 presents the simulation of building roof shading as a value determined for the whole year. From the simulation it appears that in the presented areas for which the percentage values were given (and where the monocrystalline panels have been fixed), the shading is no more than $0.5 \%$ annually, which is a very good result. Figure 4 shows the results obtained from the simulation of monthly energy yields in the first year of using the photovoltaic installation.

During the first year, it is possible to have a yield of $3759 \mathrm{kWh}$. Taking into consideration the panel efficiency decrease during the period of 25 years, the installation efficiency will reach almost $17.5 \%$ lower value, i.e. $3100 \mathrm{kWh}$ annually. Table 1 displays the annual amounts of energy yields and surpluses for the analysed building, assuming that the demand for electricity is 3000 $\mathrm{kWh}$. It should be noted that with the passage of time, more energy must be purchased from the supplier due to the the negative surpluses of electricity which occur in the simulation of the monocrystalline panel.

An average gross market price of $4.2 \mathrm{~kW}$ installation on the designed photovoltaic monocrystalline panel was assumed to be approx. 4589 euro. Adding the costs of panel assembly and taking into account the electricity costs which would be incurred when using the monocrystalline panels and comparing them with the electricity costs incurred in the same period (Table 2) the profits from using the installation can be determined.

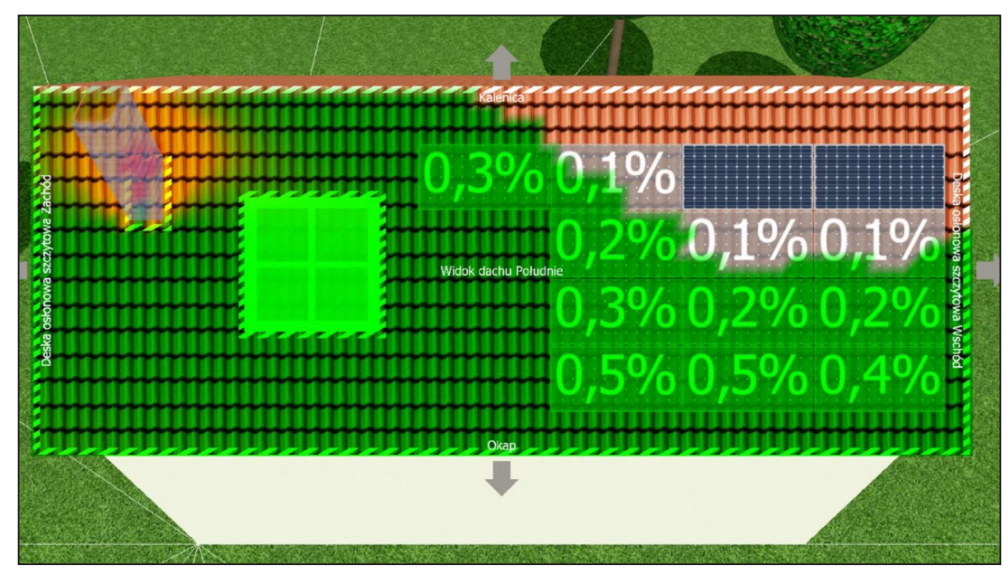

Fig. 3. Shading percentage per year for the designed monocrystalline modules 


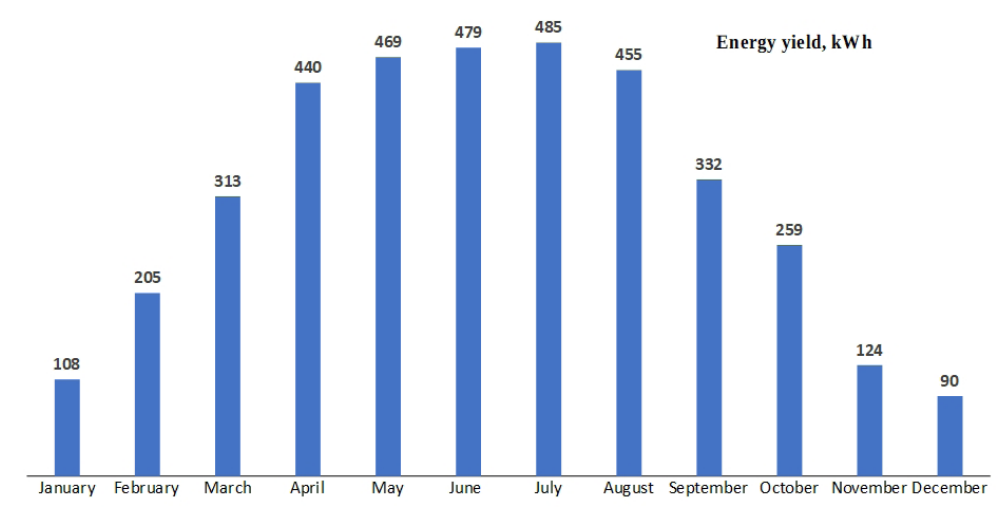

Fig. 4. Monthly energy yields from monocrystalline panels in the first year of use

They amount to 3749 euro over the period of 25 years of using it. It should be emphasised that in this case the installation will pay for itself after almost 11 years of use.

\section{Simulation variants}

In a similar way, the simulations for the photovoltaic systems based on the on-grid and offgrid polycrystalline and thin-film panels were performed. In each case, the systems provide the total power of $4.20 \mathrm{~kW}$. While using polycrystalline cells, 14 panels of $1960 \times 992 \times 40 \mathrm{~mm}$ were applied. A yearly energy yield in this case is $3866 \mathrm{kWh}$ in the first year of operation and it is almost 3\% higher than the yield acquired in the case of monocrystalline panels. It is also possible to obtain higher energy production throughout a year compared to monocrystalline panels but that does not translate into a shorter return on investment period. An advantage of such a solution involves slightly lower investment costs and higher savings of 7815 euro, which is not a significant difference compared to the installation based on monocrystalline cells.

The next variant of the simulation was using 33 thin-film panels of $1190 \times 789.5 \times 7.3 \mathrm{~mm}$. In the case of the off-grid installation, the option based on polycrystalline cells was taken into account. In such a case, a significant difference in the investment costs exist due to the necessity to store the electricity by using batteries, the price of which constitutes a substantial part of the total costs of the installation, amounting to approx. 15845 euro. It should be noted that it is a sum that exceeds the value which should be paid for electricity coming directly from the supplier, without using a photovoltaic installation. This results in a very significant, almost twofold, increase of the period of return on investment, which raises a serious question about the cost-effectiveness of using these types of installations and about using the off-grid installations in general, apart from situations in which they must be used due to lack of other possibilities.

Table 1. Summary of annual energy yields, surplus and energy required to be purchased from the supplier

\begin{tabular}{|c|c|c|c|}
\hline Year & $\begin{array}{l}\text { Auuual energy } \\
\text { yiekl (kWh) }\end{array}$ & $\begin{array}{l}\text { A umiał energy } \\
\text { sur plus (kWh) }\end{array}$ & $\begin{array}{l}\text { Arnouut of } \\
\text { energy to be } \\
\text { purchased front } \\
\text { tlie supplier } \\
\text { (kWh) }\end{array}$ \\
\hline 1 & 3759,0 & 7,2 & 0,00 \\
\hline 2 & 3728,9 & $-16,9$ & 16,88 \\
\hline 3 & 3699,1 & $-40,7$ & 40,74 \\
\hline 4 & 3669,5 & $-64,4$ & 64,42 \\
\hline 5 & 3640,1 & $-87,9$ & 87,90 \\
\hline 6 & 3611,0 & $-111,2$ & 111,20 \\
\hline 7 & 3582,1 & $-134,3$ & 134,31 \\
\hline 8 & 3553,5 & $-157,2$ & 157,23 \\
\hline 9 & 3525,0 & $-180,0$ & 179,98 \\
\hline 10 & 3496,8 & $-202,5$ & 202,54 \\
\hline 11 & 3468,9 & $-224,9$ & 224,92 \\
\hline 12 & 3441,1 & $-247,1$ & 247,12 \\
\hline 13 & 3413,6 & $-269,1$ & 269,14 \\
\hline 14 & 3386,3 & $-291,0$ & 290,99 \\
\hline 15 & 3359,2 & $-312,7$ & 312,66 \\
\hline 16 & 3332,3 & $-334,2$ & 334,16 \\
\hline 17 & 3305,6 & $-355,5$ & 355,48 \\
\hline 18 & 3279,2 & $-376,6$ & 376,64 \\
\hline 19 & 3253,0 & $-397,6$ & 397,63 \\
\hline 20 & 3226,9 & $-418,4$ & 418,45 \\
\hline 21 & 3201,1 & $-439,1$ & 439,10 \\
\hline 77 & 3175,5 & $-459,6$ & 459,59 \\
\hline 23 & 3150,1 & $-479,9$ & 479,91 \\
\hline 24 & 3124,9 & $-500,1$ & 500,07 \\
\hline 25 & 3099,9 & $-520,1$ & 520,07 \\
\hline
\end{tabular}


When comparing the discussed variants of installations for the single-family building, one should start from the price of purchase and assembly of photovoltaic panels and necessary equipment. While comparing the costs of the on-grid photovoltaic installation, it has been determined that an average price of panels and their assembly is between 4400 and 4700 euro. The polycrystalline panels are the cheapest solution and the thinfilm panels are most expensive. It should be also noted that there are price differences with various sellers and prices for the same installation may differ even by a few thousands PLN. The evident difference in prices concerns the off-grid installations, which was presented in Figure 5. When deciding about a type of photovoltaic cell technology, the price oscillates at a similar level. The price of an off-grid installation is higher due to the necessity to purchase the equipment for accumulating electricity which often exceeds the price of panels. While considering the prices, the difference in the return of PV installation costs should be mentioned. The situation is similar as in the case of assembly costs. Assuming a constant increase of energy prices and a lack of the necessity to exchange or repair a given installation, irrespective of the selected types of cells, the cost return is between 10th and 11th year of

Table 2. Profit from the use of a photovoltaic system with monocrystalline panels over a period of 25 years

\begin{tabular}{|l|c|}
\hline $\begin{array}{l}\text { Total cost of photovoltaic installation } \\
\text { and electricity }\end{array}$ & 6819 euro \\
\hline $\begin{array}{l}\text { Total cost of electricity without } \\
\text { photovoltaic installation }\end{array}$ & 14169 euro \\
\hline Profit from photovoltaic installation & 7350 euro \\
\hline
\end{tabular}

installation operation. In the case of an off-grid installation, such a cost would not be returned until 24 years of installation operation. However, it should be added that the devices such as batteries require operating costs and their periodical exchange is necessary (every 10 years). Thus, the calculations were carried out underpurely theoretical conditions in which the whole installation will operate without breakdown for 25 years and the consumer will not have the possibility to buy additional energy from the grid.

While analysing the monthly yields of each installation it can be said that they are quite similar. Minimally higher yields may be noted in the case of the on-grid polycrystalline and thin-film modules. However, there are no modules which would show evidently higher efficiency.

Taking into account the installation degradation which is approx. $20 \%$ after 25 years, it should be decided which installation will operate in a more efficient way after the elapse of such a period. It is best noticeable when observing the amount of additional energy which should be bought annually from the supplier to meet the demand for electrical energy of the building see Figure 6.

The greatest additional amounts of energy should be bought from the electrical grid in the case of installing monocrystalline modules and thin-film modules. After 25 years of installation operation, the sum will reach more than $500 \mathrm{kWh}$, i.e. approx. $1 / 6$ of the assumed demand (assuming a constant demand for all the years). What should be noted about the installation with polycrystalline modules is that it is not necessary to buy additional energy until after 5 years of operation,

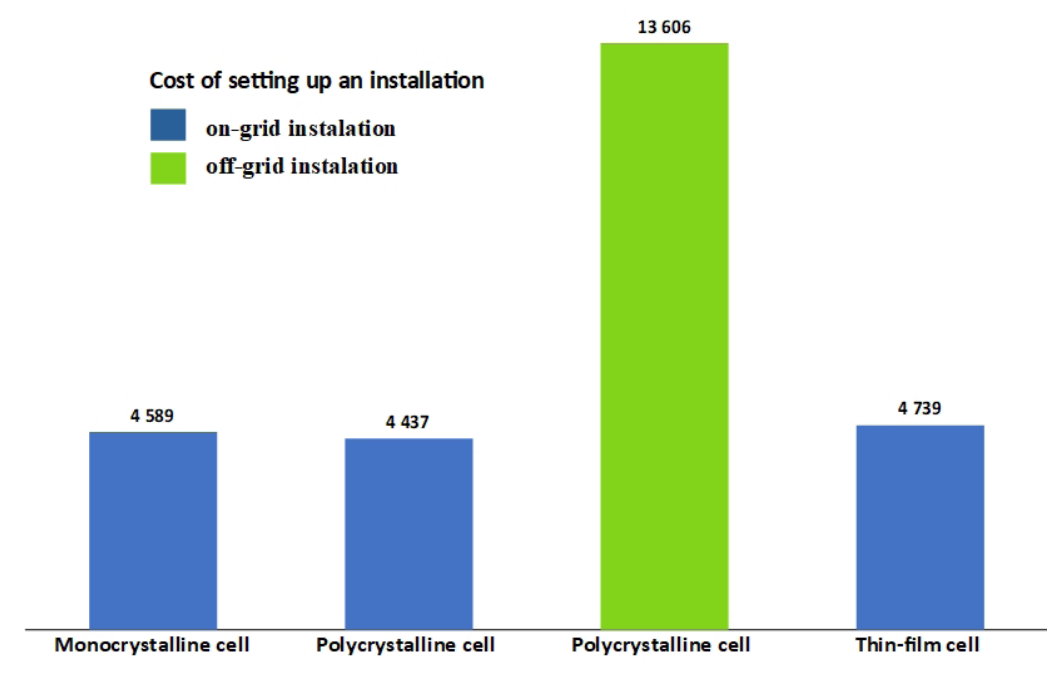

Fig. 5. Installation costs depending on the technology chosen 


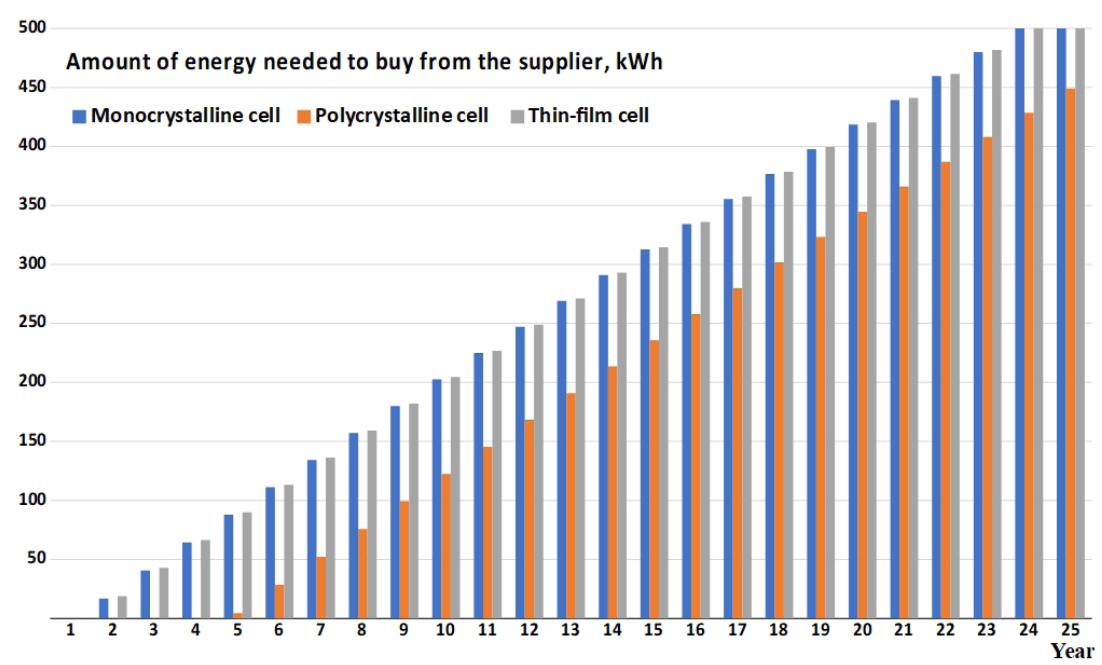

Fig. 6 The amount of electricity required to be purchased from the supplier

which translates directly to savings and significantly improves the cost-effectiveness of the installation compared to the remaining solutions. In the case of using polycrystalline modules for 25 years, it is possible to have profits which include a reduced demand for additional electrical energy of $1785 \mathrm{kWh}$. The simulation for the offgrid installation does not show an additional demand for electrical energy. Additionally, a change of energy density is noticeable depending on the technology, reaching up to $30 \%$. Such a parameter may have a significant meaning where the area with a high factor of insolation is small. It should be remembered that typical photovoltaic installations are selected by taking the profitability index as the optimisation point.

Taking into account the analysed building, the roof surface from the southern side turned out to be sufficient to meet the demand for electrical energy, irrespective of the technology of applied cells. However, if there are any obstacles such as windows, chimneys, such a comparison of technologies is of crucial importance. The thin-film modules require the largest surface but when using polycrystalline modules, the roof surface covered with PV panels can be reduced by $31.5 \%$,

Table 3. Unit energy yield for selected PV modules for $4.2 \mathrm{~kW}$ installed power

\begin{tabular}{|c|c|c|c|}
\hline Cell type & $\begin{array}{c}\text { Cell area, } \\
\mathrm{m}^{2}\end{array}$ & $\begin{array}{c}\text { Energy yield, } \\
\mathrm{kWh}\end{array}$ & $\begin{array}{c}\text { Unit energy } \\
\text { yield, } \mathrm{kWh} / \mathrm{m}^{2}\end{array}$ \\
\hline Monocrystalline & 25 & 3,759 & 149 \\
\hline Polycrystalline & 23 & 3,867 & 168 \\
\hline Thin-film & 33 & 3,881 & 115 \\
\hline
\end{tabular}

which gives very great possibilities as for the location of panels on the building roof in a convenient and not shaded place.

\section{CONCLUSIONS}

Taking into consideration all the elements of the analysis it may be definitely stated that the offgrid installation is least cost-effective. The price for assembling such an installation is even three times higher than for an on-grid installation. It results mainly from a high price of batteries, which are necessary in such types of installations. However, they may not be a totally useless and unprofitable system. They have a wide application in the places where it is not possible to connect to the power grid. Their additional advantage is that the consumer may use the whole produced energy and not only $80 \%$ of the yield like in the case of the on-grid installation ( $20 \%$ is a fee for the power plant). Such a difference is visible when it is necessary to buy additional energy from the grid after the first year of on-grid installation operation (for polycrystalline cells - after four years). In the case of the off-grid installation, such a need does not exist and for 25 years, on average, the consumer produces more energy than he uses. Moreover, in the case of the off-grid installation there are no fixed fees which would be imposed by the electrical energy seller. Nevertheless, such an installation will not pay for itself earlier than after 24 years (assuming that the system operates without breakdowns). Thus, this is a system which is more attractive for the consumers who would like 
to be more independent of the electrical energy suppliers or live in difficult conditions where it is not possible to have an electrical connection.

In the case of the on-grid installation, there are no evident differences. Each of the analysed technologies for an installation as small as a single-family building has a similar effect. The difference in installation costs is relatively small but the highest yield is observed for the cheapest and for the most expensive technologies out of the three analysed ones. However, taking into account the price and yield calculated per $1 \mathrm{~m}^{2}$ of PV panels, the technology of polycrystalline panels is the most cost-effective investment. They are the cheapest ones among the analysed ones and they make the highest benefits, not only in terms of electricity but also finances. Interestingly, after the first year of monocrystalline and thin-firm installation operation, it is necessary to buy additional electricity from the grid. In this regard, the polycrystalline modules turned out to be most profitable as such a necessity does not exist in their case for the first 4 years. Photovoltaic installations are a solution which is more and more frequently used in Europe, not only due to the environmental protection but also due to the economical reasons. The EU subsidies are also very popular. They significantly decrease the investment costs which still constitute a relatively high expense for an average household.

There are many photovoltaic cell technologies available on the market. Silicon (monocrystalline and polycrystalline) cells have been used most frequently for years. Newer technologies are more expensive, but they do not always go hand in hand with an increase of efficiency. It should be also stressed that the thin-film technologies are used in lightweight applications (such as boats, cars, drones), in which a weight of the installation and adjustment of the installation to the shape of the surface (due to their flexibility) play an important role. For small photovoltaic installations, the choice of technology will not be very significant. The differences between them are minimal both in terms of installation costs and annual yields. However, when taking into account the energy density and return on investment, polycrystalline panels turn out to be an optimal solution. The investment cost is the main point of deliberations on whether photovoltaics is a real alternative for the traditional sources of energy acquisition. However, it should be remembered that the leading aim of alternative sources of energy are not financial aspects but minimisation of carbon dioxide emission to the atmosphere. If it is possible to produce clean energy and there are suitable conditions for that to occur, it is worth remembering about future generations.

\section{REFERENCES}

1. American Physical Society, April 25, 1954: Bell Labs demonstrates the first practical silicon solar cell. APS News 2009, 18(4).

2. Góralczyk I., Tytko R., 2015. Photovoltaics devices, photovoltaic and electrical installations (in Polish). 2nd Edition, Kraków.

3. Adeeb J,. Farhan A., Al-Salaymeh A. 2019. Temperature effect on performance of different solar cell technologies. Journal of Ecological Engineering, 20(5), 249-254.

4. Hoa Thanh Nguyen H.T., Nguyen L., Thi Lan P.D. 2019. Optimization of Copper Removal by Photovoltaic Electrocoagulation from Aqueous Solution Using Response Surface Methodology Towards Sustainable Development. Journal of Ecological Engineering, 20(7), 103-111.

5. Klugmann-Radziemska E., 2014. Postępy fotowoltaiki - aktualne technologie produkcji ogniw. Czysta Energia, 5(143), 40-42.

6. Szymański B. 2013. Small photovoltaic installation (in Polish). GLOB Energia, Kraków.

7. Rabczak S., Proszak-Miasik D. 2016. Effect of the type of heat sources on carbon dioxide emission. Journal of Ecological Engineering, 17(5), 186-191. 